Schriften zum Internationalen und

Europäischen Strafrecht

Lutz Eidam | Michael Lindemann | Andreas Ransiek (eds.)

Interrogation, Confession,

and Truth

Comparative Studies in Criminal Procedure 
Schriften zum Internationalen und

Europäischen Strafrecht

Edited by

Professor Dr. Martin Heger, Humboldt-Universität zu Berlin Professor Dr. Florian Jeßberger, Universität Hamburg Professor Dr. Frank Neubacher, M.A., Universität zu Köln Professor Dr. Helmut Satzger, LMU München Professor Dr. Gerhard Werle, Humboldt-Universität zu Berlin

Volume 43 


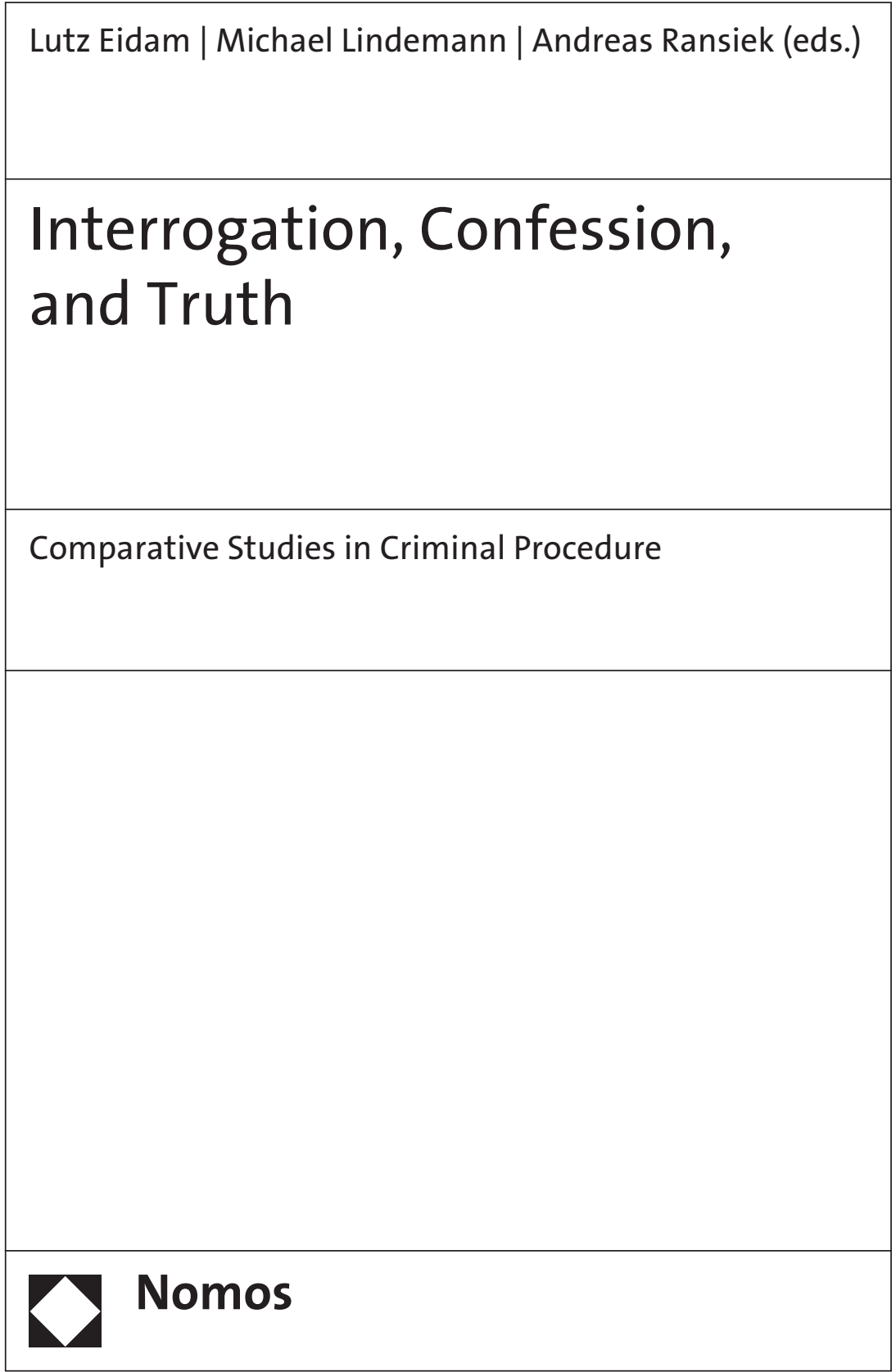

(C) NOMOS Verlagsgesellschaft 
The Deutsche Nationalbibliothek lists this publication in the Deutsche Nationalbibliografie; detailed bibliographic data are available on the Internet at http://dnb.d-nb.de

ISBN

$$
\begin{aligned}
& \text { 978-3-8487-6330-6 (Print) } \\
& \text { 978-3-7489-0438-0 (ePDF) }
\end{aligned}
$$

\section{British Library Cataloguing-in-Publication Data}

A catalogue record for this book is available from the British Library.

ISBN

$$
\begin{aligned}
& \text { 978-3-8487-6330-6 (Print) } \\
& \text { 978-3-7489-0438-0 (ePDF) }
\end{aligned}
$$

\section{Library of Congress Cataloging-in-Publication Data}

Eidam, Lutz / Lindemann, Michael / Ransiek, Andreas

Interrogation, Confession, and Truth

Comparative Studies in Criminal Procedure

Lutz Eidam / Michael Lindeman / Andreas Ransiek (eds.)

214 pp.

ISBN 978-3-8487-6330-6 (Print)

978-3-7489-0438-0 (ePDF)

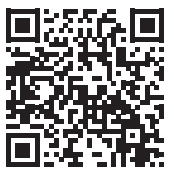

Onlineversion

Nomos eLibrary

1st Edition 2020

(c) Nomos Verlagsgesellschaft, Baden-Baden, Germany 2020. Printed and bound in Germany.

This work is subject to copyright. All rights reserved. No part of this publication may be reproduced or transmitted in any form or by any means, electronic or mechanical, including photocopying, recording, or any information storage or retrieval system, without prior permission in writing from the publishers. Under $\$ 54$ of the German Copyright Law where copies are made for other than private use a fee is payable to "Verwertungsgesellschaft Wort", Munich.

No responsibility for loss caused to any individual or organization acting on or refraining from action as a result of the material in this publication can be accepted by Nomos or the editors. 


\section{Introduction}

Originally, the defendant's interrogation was regarded mainly as an element of her or his right to be heard in criminal proceedings. Although this concept is still appealing in theory, the picture has changed in reality. Nowadays, interrogation follows a different purpose: a confession of the crime shall be obtained.

The purpose of criminal procedure is to convict the guilty and protect the innocent - but the innocent only. Many prosecutors and judges seem to assume that somebody voluntarily confessing a crime clearly must be guilty. This is not only true for an inquisitorial system of criminal procedure but for the adversarial process as well. If the defendant confesses in the early stages of criminal proceedings, especially while being interrogated by the police, things are clear before the trial even starts. The cat is out of the bag and the defendant generally stands no chance to successfully revoke her or his admission of the crime.

By interrogating the defendant the truth shall be found. To this end some pressure on the defendant and some trickery if not outright deceptions are deemed appropriate to uncover the true events that took place and constitute the crime. This does not mean that police brutality is generally welcomed. But when it comes to the prevention of terroristic attacks or the rescue of an innocent party, even brutality is not necessarily considered absolutely banned.

On the other hand, both in Europe and the United States, the privilege against self-incrimination is guaranteed as a basic right of the accused, explicitly guaranteed by the $5^{\text {th }}$ Amendment to the U.S. Constitution and mandated by both the protection of human dignity and by the rule of law of Germany's Basic Law. It is a necessary element of a fair hearing according to the European Court of Human Rights. It is "one of our nation's most cherished principles" as Chief Justice Earl Warren wrote for the majority opinion in Miranda v. Arizona. While it is widely accepted, too, that a defendant's rights should not "handcuff" the police, it is common opinion that torture to obtain a confession is forbidden in regular criminal proceedings. Any recourse to physical force by the police which has not been made strictly necessary by the person's conduct diminishes human dignity and is a violation of the European Convention of Human Rights according to the European Courts. 
However, the legal demands are ambiguous when it comes to more subtle means of obtaining a confession. Does slapping a person once or twice constitute torture? Even if the answer is affirmative, we still have to consider what Fred Inbau wrote in 1961: "I am unalterably opposed to the use of any interrogation technique that is apt to make an innocent person confess. (...) I do approve of such psychological tactics and techniques as trickery and deceit (...) to secure incriminating information from the guilty.' So maybe, as a German law professor wrote in the 1970s, the defendant's choice to remain silent is nothing but an artful "trick" obstructing the truth finding process and the administration of justice.

Thus, the question is where the line has to be drawn. Is it sufficient to warn defendants that they have a right to remain silent and to have the assistance of a lawyer for their defense? What is the current status of the privilege against self-incrimination? Should a resulting confession be inadmissible if warnings were not given like Miranda v. Arizona stipulated in 1966 and the German Federal Criminal Court acknowledged some 25 years later as well? When has someone's will been overborne and governing self-direction is lost, as Justice Felix Frankfurter put it in 1961? When, on the other hand, is truth discovered? More fundamentally: what is this thing called truth?

Scholars from the Unites States, the Netherlands, and Germany have discussed these issues from their respective legal backgrounds and experiences in May 2019 at Bielefeld University and have contributed the papers you find in this volume. We were delighted to have you here for such a successful workshop!

Andreas Ransiek

Michael Lindemann

Lutz Eidam 


\section{Content}

List of Contributors 9

The Suspect as a Source of Information 11

Thomas Weigend

Pretrial Self-Incrimination, Miranda, and Truth

Anthony O'Rourke

Contemporary Problems of the Right to Remain Silent in Germany

Lutz Eidam

The Legality of Trickery During Interrogation

Christopher Slobogin

The Mr. Big Method: On or Beyond the Boundaries of Lawfulness and Reliability?

D.A.G. van Toor / R. Horselenberg

Erosion of the Right to Silence in Dutch Criminal Justice?

J.H. Crijns / M.J. Dubelaar

Self-Incrimination Privilege and Interrogation. A German and Comparative View

Andreas Ransiek

Structural Police Deception in American Police Interrogation:

A Closer Look at Minimization and Maximization

Richard A. Leo

Report on the Comparative Conference on Criminal Procedure at Bielefeld University, Interrogation, Confession, and Truth, 21 - 22 May 2019

Alexandra Westermann / Matthias Newerla 
(C) NOMOS Verlagsgesellschaft 


\section{List of Contributors}

Crijns, Jan H., Faculteit der Rechtsgeleerdheid, Universiteit Leiden, Nederland.

Dubelaar, Marieke J., Faculteit der Rechtsgeleerdheid, Radboud Universiteit, Nijmegen, Nederland.

Eidam, Lutz, Fakultät für Rechtswissenschaft, Universität Bielefeld, Deutschland.

Horselenberg, Robert, Faculteit der Rechtsgeleerdheid, Universiteit Maastricht, Nederland.

Leo, Richard A., University of San Francisco School of Law, USA.

Newerla, Matthias, Fakultät für Rechtswissenschaft, Universität Bielefeld, Deutschland.

O'Rourke, Anthony, Advocacy Institute, University at Buffalo School of Law, USA.

Ransiek, Andreas, Fakultät für Rechtswissenschaft, Universität Bielefeld, Deutschland.

Slobogin, Christopher, Vanderbilt University Law School, Nashville, USA.

Toor Dave van, Willem Pompe Institute for Criminal Law and Criminology, Utrecht University, Nederland. 
Weigend, Thomas, Rechtswissenschaftliche Fakultät, Institut für ausländisches und internationales Strafrecht, Universität zu Köln, Deutschland.

Westermann, Alexandra, Fakultät für Rechtswissenschaft, Universität Bielefeld, Deutschland. 


\title{
Erosion of the Right to Silence in Dutch Criminal Justice?
}

\author{
J.H. Crijns" / M.J. Dubelaar
}

1. Introduction

2. Interrogation of the suspect or accused in Dutch criminal justice

3. Origins and rationale of the right to silence

4. Exploring the scope of the right to silence in the Netherlands

5. Ways to circumvent the right to silence

5.1 Use of trickery

5.2 The 'Mr. Big' technique

5.3 Adverse inferences

5.4 Evidentiary presumptions

6. Conclusion

\section{Introduction}

The right to silence is one of the corner stones of criminal procedural law and is embedded in many jurisdictions in one way or another. This is also the case in the Netherlands, where the right to silence has a firm legal basis in the Dutch Criminal Code of Procedure (hereafter: DCCP). As a result of the Salduz case law of the European Court of Human Rights ${ }^{1}$ and European legislation on the right of access to a lawyer ${ }^{2}$, the right to silence has

* Jan H. Crijns is Professor of Criminal Law and Criminal Procedure at Leiden University.

\# Marieke J. Dubelaar is Associate Professor of Criminal Law and Criminal Procedure at Radboud University Nijmegen.

1 See e.g. Salduz v. Turkey, ECtHR (GC) 27 November 2008, no. 36391/02.

2 See Directive 2013/48/EU of the European Parliament and of the Council of 22 October 2013 on the right of access to a lawyer in criminal proceedings and in European arrest warrant proceedings, and on the right to have a third party informed upon deprivation of liberty and to communicate with third persons and with consular authorities while deprived of liberty, OJ 2013, L 294/1. 
been further strengthened in the Dutch legal order by granting the defendant the right to consult a lawyer before police interrogations start and to have a lawyer present during these interrogations, who can protect his client against involuntary self-incrimination. In 2016, the importance of the right to silence as a fundamental right was further stressed by adopting the EU Directive on the presumption of innocence. ${ }^{3}$ However, at the same time Dutch case law increasingly seems to allow for more practices that infringe on the right to silence. Examples of such practices are the use of trickery to elicit a statement from the suspect or accused or the drawing of adverse inferences from a refusal of the suspect or accused to give a statement. This chapter focuses on the right to silence and the many ways in which the right to silence can nowadays be restricted and circumvented in the Netherlands $(\$ 5)$, as seems to be the case in many other Western criminal justice systems also. ${ }^{4}$ At the end of the chapter, we will raise (and provide a beginning of an answer to) the question which rationales of the right to silence are still protected in the Netherlands, given the many ways to circumvent it or to minimize its effects $(\$ 6)$. First, we will discuss the important role of the interrogation of the suspect or accused in the Netherlands and the position of the right to silence in Dutch criminal procedure $(\$ 2)$, the origins and the rationale of the right to silence in general $(\$ 3)$ and the scope of the right to silence in Dutch criminal procedure ( $\$ 4)$.

\section{Interrogation of the suspect or accused in Dutch criminal justice}

The Dutch criminal justice system - like many continental criminal justice systems - is based on the inquisitorial tradition. ${ }^{5}$ Although the case law of the European Court of Human Rights has 'forced' the Dutch system to

3 See Directive 2016/343/EU of the European Parliament and of the Council of 9 March 2016 on the strengthening of certain aspects of the presumption of innocence and of the right to be present at the trial in criminal proceedings, OJ 2016, L 65/1.

4 See e.g. H. Quirk, The Rise and Fall of the Right of Silence, London and New York: Routledge 2017, where she describes the implications of the curtailment of the right to silence in England, Wales and Northern Ireland as a result of the Criminal Justice and Public Order Act 1994.

5 See for a comprehensive introduction into the Dutch criminal justice system: P.H.P.H.M.C. van Kempen, M. Krabbe and S. Brinkhoff (eds.), The Criminal Justice System of the Netherlands. Organization, Substantive Criminal Law, Criminal Procedure and Sanctions, Antwerp: Intersentia 2019. See also J.H. Crijns and M.A.H. van der Woude, 'The Criminal Justice System; in: J. Chorus, E.H. Hondius and W.J.M. Vo- 
adopt several adversarial elements, the inquisitorial character of the Dutch system is still recognizable. ${ }^{6}$ As in most inquisitorial systems, the statements of the suspect or accused play a very important role in proving someone's guilt. Despite the rise of all kinds of sophisticated forensic techniques, the confession is still regarded by many as the Regina Probationum ('the Queen of Evidence'). And although criminal justice actors are aware of the fact that some confessions might be false, the defendant often provides valuable information for the process of truth-funding. For this reason, in Dutch criminal justice the suspect or accused is questioned at all stages of the proceedings: from the very beginning during police investigations until the very end at trial. At all stages of criminal proceedings, the suspect or accused is not only regarded as the defending party with his own legal position, but also - and at the early stages of the proceedings, almost primarily - as a useful source of information in the process of establishing the truth.

At this point, something of a paradox arises: at trial the defendant is instructed that he does not need to answer any question, but nevertheless questions are being asked by the same judges who later on will pass a verdict. The defendant does not need to take an oath, however. In this respect, the Dutch and the German systems differ, for example, from the criminal justice system of England and Wales. In that system if the defendant decides to give a statement, he has to take an oath and risks being prosecuted for perjury when he does not tell the truth. ${ }^{7}$ In the Netherlands, the defendant cannot perjure himself, but once he decides to give a statement, his statements can be used against him.

Given the importance of the statements of the suspect or accused in Dutch criminal proceedings, it is of utmost importance to have certain safeguards in place that can protect the suspect or accused from involuntary self-incrimination. Therefore, the right to silence - as part of the privilege against self-incrimination - has a prominent place in the Dutch Code of Criminal Procedure. The right to remain silent is set forth in article 29 DCCP, which provides as follows:

ermans (eds.), Introduction to Dutch Law, Alphen aan den Rijn: Kluwer Law International 2016, p. 441-474.

6 See for the consequences this inquisitorial character has for the process of truthfinding C.H. Brants and S. Field, 'Truth-finding, procedural traditions and cultural trust in the Netherlands and England and Wales: When strengths become weaknesses', The International Journal of Evidence and Proof 2016 (20), 4, p. 266-288.

7 See 'Perjury by Defendants: The Uses of Double Jeopardy and Collateral Estoppel', Harvard Law Review 1961, 4, p. 752-764. 
1. In all cases where a person is being questioned as a suspect or defendant, the judge or official who is conducting the questioning, shall refrain from any act aimed at obtaining a statement which cannot be said to have been freely given. The suspect or the defendant shall not be obliged to answer any questions.

2. Before the suspect or the defendant is questioned, he shall be informed that he is not obliged to answer any questions.

In other words, not only can the suspect or accused exercise his right to remain silent during any interrogation (article 29, paragraph 1), he must also be informed of this right before the questioning starts (article 29, paragraph 2), which may be understood as the continental manifestation of the Miranda-warning. On top of that, paragraph 1 expressly forbids the use of coercion during questioning. It is clear that this provision excludes the use of any form of torture or inhuman or degrading treatment during interrogation within the meaning of Article 3 ECHR. According to the Dutch Supreme Court, however, this provision does not entail a ban on any form of pressure during the interrogation. This provision does not necessarily preclude very long interrogations or the practice of 'informing' the suspect or accused of the consequences of his choices during interrogation. However, the line with threatening or intimidating the suspect or accused, which obviously is not allowed, is rather thin. And, as we will discuss later on in the chapter, some amount of trickery during interrogation may also be overlooked by the Dutch Supreme Court. ${ }^{8}$ As a result, the exact scope of the prohibition of coercion during the interrogation is rather vague and subject to continuing debate in the case law. ${ }^{9}$

The right to remain silent is closely connected to the right to have access to a lawyer and to have him present during the interrogation. Early access to a lawyer puts the suspect or accused in a position to choose whether or not to give a statement and provides for some form of monitoring over the way the suspect or accused is interrogated. At the supranational level also, the lawyers' role is, among other things, to protect his client against involuntary self-incrimination. ${ }^{10}$ Historically, in the Netherlands, there has been resistance against the idea of having a lawyer present during police interro-

8 See e.g. Supreme Court of the Netherlands 9 January 2018, ECLI:NL:HR:2018:18. See for further details section 5.1.

9 See e.g. G.J.M. Corstens, Het Nederlands strafprocesrecht, $9^{\text {th }}$ edition, updated by M.J. Borgers and T. Kooijmans, Deventer: Wolters Kluwer 2018, p. 323-324.

10 In the words of the ECtHR: 'Early access to a lawyer is part of the procedural safeguards to which the Court of Human Rights will have particular regard when ex- 
gations, which has to do with the Dutch criminal justice system's inquisitorial roots and the important role that the confession of the suspect or accused plays in the process of truth-finding. As already mentioned in the introduction, thanks to influence of European guidelines and the case law of the ECtHR, Dutch suspects nowadays have the right to consult a lawyer before the first police interrogation starts and to have him present during all interrogations (articles $28 \mathrm{c}-28 \mathrm{~d}$ DCCP). In theory at least, protecting the right of access to a lawyer at the time of questioning serves to strengthen the right to silence, especially since the lawyer is not only allowed to be present, but also to participate effectively, meaning that he is also entitled to advise his client during interrogation, for instance on exercising his right to silence.

\section{Origins and rationale of the right to silence}

Although the right to silence is considered one of the corner stones of modern criminal justice, its origins and rationale(s) are much more blurry than its present status would suggest. ${ }^{11}$ It is not the purpose of this chapter to discuss the history of the right to silence in the Netherlands extensively, but it is important to stress here that the legal protection of the right to silence is a relatively new development. As a relic of true inquisitorial times, until the end of the nineteenth century, in the Netherlands, the suspect was obliged to give statements, although this obligation was no longer enforceable since the abolition of the rack in 1789. Nevertheless, it was not until 1926 - when the current Dutch Code of Criminal Procedure came into force - that the right to silence was officially recognized in the Dutch criminal justice system. The main reason for this was the wish to prevent the suspect or accused from methods of oppression or coercion during interrogation, and, by doing so, to further 'humanize' criminal justice. ${ }^{12}$ Further, there was a growing awareness that the right to silence need not only

amining whether a procedure has extinguished the very essence of the privilege against self-incrimination'. See e.g. Salduz v. Turkey, ECtHR (GC) 27 November 2008 , no. 36391/02, $\$ 54$.

11 See e.g. Quirk 2017, p. 11-15. See extensively on the history of the right to silence in the Netherlands, L. Stevens, Het nemo-teneturbeginsel in strafzaken: van zwijgrecht naar containerbegrip (diss. Tilburg), Nijmegen: Wolf Legal Publishers 2005, p. $40-55$.

12 See Parliamentary Papers II 1913/14, 286, no. 3 (Explanatory Memorandum), p. 71. See also Stevens 2005, p. 66. 
hamper the process of truth-finding, but may also contribute to it, since a strict obligation to give statements may also lead to false statements, with all that this entails. In the course of the twentieth century, under the influence of the case law of the ECtHR, the foundations of the right to silence became even stronger, with the ECtHR considering the right to silence to be an indispensable part of the right to a fair trial. Nowadays, generally speaking, three different but interrelated rationales for the right to silence may be distinguished: 1) Preventing the suspect or accused from undue pressure during interrogation; 2) Securing the reliability of the statements of the suspect or accused and preventing miscarriages of justice; and 3) Granting autonomy to the suspect or accused during criminal proceedings as part of the right to a fair trial. ${ }^{13}$ In the following paragraphs we will briefly explain each of these three rationales.

The strong wish to prevent the suspect or accused from undue pressure during interrogation may be considered the moving force behind the right to silence. Even before the realization of the ECHR there was a growing awareness that a criminal justice system should not allow recourse to violence and threats during the interrogation of the suspect or accused. Granting him the right to silence was considered the most effective way to prevent the suspect or accused from torture or other inhuman interrogating techniques. Needless to say, this rationale for the right to silence became even stronger after the realization of the ECHR, which, among other things, provides protection against torture and inhuman or degrading treatment. Apart from granting the suspect or accused the right to silence as an individual right, in most criminal justice systems this rationale is further strengthened by an explicit prohibition for the authorities to exercise undue pressure during interrogation. ${ }^{14}$ As a mirror image, this instruction norm for the authorities may be understood as providing for an individual right of the suspect or accused to be protected from undue pressure while being interrogated.

13 See Corstens 2018, p. 322. See also Saunders v. United Kingdom, ECtHR (GC) 17 December 1996, no. 19187/91, $\$ 68$.

14 See for the Dutch criminal justice system article 29, paragraph 1, DCCP. See also Ibrahim and Others $v$. the United Kingdom, ECtHR (GC) 13 September 2016, no. $50541 / 08, \mathbb{2} 267$ : 'It is important to recognise that the privilege against self-incrimination does not protect against the making of an incriminating statement per se but, as noted above, against the obtaining of evidence by coercion or oppression. It is the existence of compulsion that gives rise to concerns as to whether the privilege against self-incrimination has been respected.' 
However, the wish to protect the suspect or accused from undue pressure while being interrogated is not the only rationale underlying the right to silence. The importance of this right can also be sought in epistemological reasons. When truth-finding is considered to be one of the main goals of criminal procedure, ${ }^{15}$ it would not make much sense to force a suspect or accused to answer questions during interrogation. Forcing a suspect or accused to give answers raises the risk of unsafe convictions and miscarriages of justice (quite apart from the question of the legality of the means adopted to achieve this), since the suspect or accused who cannot invoke the right to silence would be placed with a dilemma: either give true statements or lie (with all that this entails in those jurisdictions providing for the crime of perjury). ${ }^{16}$ One could argue that only those who are actually guilty will consider this a true dilemma, since innocent persons will always choose to tell the truth given that it is in their interests to do so. However, this argument overlooks the fact that people can have many other reasons to withhold a statement or to give false statements, even when they are innocent of the crime of which they are suspected or accused. Accordingly, from the perspective of the quality of the process of truth-finding (as one of the main goals of criminal proceedings) also, it is essential to take the right to silence seriously.

The third rationale for the right to silence is the wish to grant the suspect or accused a certain degree of autonomy to determine his own position during criminal proceedings, as a concrete manifestation of the right to a fair trial. In this respect, the right to silence - although not expressly provided for in article 6 ECHR - is often mentioned in connection with such other essential fair trial rights as the privilege against self-incrimination and the presumption of innocence. ${ }^{17}$ However, the answer to the question of how these fundamental rights interrelate is not self-evident and subject to ongoing debate in the legal scholarship. ${ }^{18}$ What this connection with these other fundamental rights shows, however, is that, nowadays, the

15 See e.g. L. Laudan, Truth, Error, and Criminal Law. An Essay in Legal Epistemology, New York: Cambridge University Press 2006.

16 See also M. Redmayne, 'Rethinking the Privilege Against Self-Incrimination', $O x$ ford Journal of Legal Studies 2007, 2, p. 221-222.

17 See e.g. Quirk 2017.

18 See in this regard e.g. two recent Dutch dissertations: J.H.B. Bemelmans, Totdat het tegendeel is bewezen. De onschuldpresumptie in rechtshistorisch, theoretisch, internationaalrechtelijk en Nederlands strafprocesrechtelijk perspectief (diss. Nijmegen), Deventer: Wolters Kluwer 2018; and A. Zeeman, Dulden of meewerken? Een onderzoek naar de toepassing van het nemo tenetur-beginsel bij de sfeerovergang van controle naar opsporing (diss. Rotterdam), 's-Hertogenbosch: Gompel \& Svacina 2019. See also 
right to silence is tied up with the right to a fair trial as provided for in Article 6 ECHR. ${ }^{19}$ Although not always supported by public opinion, there is a strong communis opinio among legal scholars that the right to refuse to answer questions during interrogation is a matter of fairness. At the same time, it is unclear why this is the case, i.e. why compelling the suspect or accused to answer questions during interrogation should be considered unfair (aside from the illegality of the methods adopted to achieve this). As will be explained in section 4, Dutch administrative law is based on the obligation to cooperate, including the obligation to give certain information upon request. ${ }^{20}$ In the context of criminal justice, however, compelling a suspect or accused to answer is out of the question. The main rationale for this seems to be the wish to afford the suspect or accused a certain degree of autonomy with regard to his own position, for as long as he is involved in criminal proceedings. It is here that the relationship with the presumption of innocence, pursuant to which the suspect or accused is to be considered innocent until proven guilty and the burden to establish guilt is on the prosecution, becomes clear. From the perspective of this presumption, it would not make much sense to oblige the suspect or accused to cooperate with the prosecution and to compel him to answer to questions during interrogation. Therefore, taking the presumption of innocence seriously also implies recognizing the right to silence. In this line of reasoning, it is principally up to the suspect or accused whether he cooperates in his own prosecution. However, according to the case law of the ECtHR, this is only true when it comes to information which is dependent for its existence on the will of the suspect or accused, i.e. his statements.

on the interrelation of the right to silence and the privilege against self-incrimination Stevens 2005.

19 See Saunders v. United Kingdom, ECtHR (GC) 17 December 1996, no. 19187/91, $\$ 68$, where the ECtHR describes the right to silence and the privilege against selfincrimination as 'generally recognised international standards which lie at the heart of the notion of a fair procedure under Article 6. The right to remain silent is also acknowledged by the Court of Justice of the European Union. See A.H. Klip, European Criminal Law. An Integrative Approach, $3^{\text {rd }}$ edition, Cambridge: Intersentia 2016, p. 274, with reference to inter alia Limburgse Vinyl Maatschappij and others v. Commission, CJEU 15 October 2002, C-238/99 P. See also Article 7 of the Directive 2016/343/EU of the European Parliament and of the Council of 9 March 2016 on the strengthening of certain aspects of the presumption of innocence and of the right to be present at the trial in criminal proceedings, OJ 2016, L 65/1.

20 Although an administrative punitive sanction cannot be grounded on information obtained by means of enforcing the obligation of cooperation, because of the privilege against self-incrimination and the right to silence. See for references and further details section 4 . 
When it comes to information that has existence independent of the will of the suspect or accused, the privilege against self-incrimination does not provide much protection. ${ }^{21}$ As a result of this case law, the privilege against self-incrimination and the right to silence overlap significantly. It is not the purpose of this chapter to determine the exact relationship between the presumption of innocence, the privilege against self-incrimination and the right to silence, ${ }^{22}$ but it is important to point out that the right to silence is strongly connected to these fundamental rights and to the right to a fair trial more generally.

For the remainder of this chapter, the three rationales for the right to silence set out above will serve as analytical tools in explaining, interpreting and assessing the various ways in which the right to silence may be circumvented or curtailed. At the end of this chapter, we will discuss the extent to which these rationales may (still) be discerned in the Dutch criminal justice system, given the apparent curtailment of the right to silence in the case law.

\section{Exploring the scope of the right to silence in the Netherlands}

In the next section we will shift our focus to the various ways in which the right to silence may be circumvented in the Netherlands. In this section, we will take a closer look at the wording of article 29 DCCP itself, from which some inherent limitations of this right already emerge.

First, this right is only applicable when someone is considered a suspect. As long as someone is not considered a suspect, law enforcers - including police officers - can ask any question without having the legal duty to inform the person of his right to remain silent. This has important consequences for investigations in the context of other legal domains than criminal law, such as administrative law. In this context, citizens are obliged to cooperate with the law enforcement authorities by sharing information, without being able to invoke the privilege against self-incrimination or the right to silence. This obligation can put individuals in a difficult legal position when this information ultimately could lead to a suspicion of a crime. Is the legal obligation to cooperate still applicable and enforceable in such a situation, despite the fact that the individual concerned might incriminate himself by providing information? The answer is affirmative; he

21 See for further details section 4.

22 See further on this interrelation Bemelmans 2018, p. 99-101. 
still has to cooperate. However, when this information ultimately gives rise to criminal proceedings or to a punitive administrative sanction (e.g. an administrative fine), the information which has been obtained under the threat of this legal obligation to cooperate may not be used as evidence in the context of this criminal charge. ${ }^{23}$

Furthermore, logically the right to silence only applies to (oral) statements. Here it should be recalled, however, that the overarching privilege against self-incrimination is also limited in its scope. According to case law of the ECtHR, material obtained from the accused through recourse to compulsory powers but which has an existence independent of the will of the suspect - such as documents, breath, blood and urine samples, and bodily tissue for the purpose of DNA-testing - falls outside the scope of the privilege. ${ }^{24}$ This means that the suspect has to cooperate or at least refrain from resisting against the exercise of compulsory powers in relation to material that has an existence independent of the will of the suspect. Therefore, the right to silence and the related privilege against self-incrimination are at the outset significantly limited in their scope. Although this distinction may be self-evident, it may also lead to rather curious and somewhat arbitrary situations, for instance when it comes to unlocking a smartphone. Because of the right to silence, a police officer cannot force a suspect to give the password of his smartphone; according to some lower courts in the Netherlands, however, a police officer is entitled to unlock the same smartphone by pressing the suspects finger(print) on the device. $^{25}$

23 See Saunders v. United Kingdom, ECtHR (GC) 17 December 1996, no. 19187/91, $\$ 74$ : 'It is noteworthy in this respect that under the relevant legislation statements obtained under compulsory powers [...] cannot, as a general rule, be adduced in evidence at the subsequent trial of the person concerned. See for further details R. Stijnen, Rechtsbescherming tegen bestraffing in het strafrecht en het bestuursrecht. Een rechtsvergelijking tussen het Nederlandse strafrecht bestraffende bestuursrecht, mede in Europees perspectief (diss. Rotterdam), Deventer: Kluwer 2011, p. 616-627.

24 See Saunders v. United Kingdom, ECtHR (GC) 17 December 1996, no. 19187/91, $\$ 69$, and O'Halloran and Francis $v$. the United Kingdom, ECtHR (GC) 29 June 2007, nos. 15809/02 and 25624/02, $\$ 47$.

25 See e.g. District court of Noord-Holland 28 February 2019, ECLI: NL: RBNHO: 2019:1568, $\$ 3.4$. 


\section{Ways to circumvent the right to silence}

As we have discussed earlier, the right to silence is considered a fundamental right, which also has a firm legal basis in the Dutch Code of Criminal Procedure. This does not mean however, that this right is absolute and does not allow for any exceptions. ${ }^{26}$ As will become apparent in this section, several ways exist to circumvent this right or to limit the effects of a defendant invoking his right to silence. Examples are the use of (some forms of) trickery or the drawing of negative inferences from the defendant's decision not to give a statement or to provide additional information to substantiate his version of what happened.

\subsection{Use of trickery}

One example of circumventing the right to silence is the use of trickery during the investigation. In the Netherlands, much debate arose over a particular case in which the police tricked the defendant into providing incriminating information. It concerned a robbery on a house during the night where the inhabitants were threatened. Because the police had not made any progress in the investigation of the crime, they decided to make mention of an imaginary loot in the interrogation of the suspect for the sole purpose of getting the conversation going between him and the other suspect in this case (who were brothers) afterwards. Before doing so they placed monitoring equipment in the taxi which brought them both home following the police interrogations. The monitored conversations showed that both brothers were indeed involved in the robbery, as the police suspected. ${ }^{27}$

In the Netherlands, the technique or strategy employed by the police is known as the 'ruisstrategie' (literally translated: 'noise strategy'). This method is characterized by the police giving false information to the suspect in order to elicit incriminating information from the suspect that could help forward the investigation. In other words, the police creates 'noise' or disturbance in the hope that the suspect acts upon it, for example by speaking to others or looking on the internet. The noise or disturbance

26 See e.g. John Murray v. the United Kingdom, ECtHR (GC) 8 February 1996, no. 18731/91, $\$ 47$; and Ibrahim and Others $v$. the United Kingdom, ECtHR (GC) 13 September 2016, no. 50541/08, \$269.

27 See Supreme Court of the Netherlands 9 January 2018, ECLI:NL:HR:2018:18. 
is part of a technical plan in which the police monitors the behavior of the suspect by using monitoring equipment, for which permission of the public prosecutor and in some cases the investigative judge is necessary.

There is no information available on how often the police uses this type of strategy, and it surfaces in newspaper articles and in the jurisprudence only occasionally. Apparently, the police employ a wide variety of tactics, mostly in cases in which the investigation is deadlocked. Another tactic employed by the authorities is the publication of fake news. In a case involving a prostitute who had been badly beaten up while being robbed, the police used this tactic by publishing a fake article in the local newspaper, which reported a possible breakthrough in the case. ${ }^{28}$ To make sure that the suspect would read the paper, the police delivered the paper to the suspect's house themselves, already unfolded at the page of the article, to ensure that the defendant would see it. In the following days, the police intensively monitored the suspect's telephone and internet communications, in the hope that he would incriminate himself, without success however. Another tactic is to create disturbance among family members of the suspect by giving them false information in the hope this would lead the suspect to talk. For example, the police used this tactic in a case of maltreatment of a baby, leading to its death. In this case, the police withheld the autopsy report for some time, placed monitoring equipment in the house and bedroom of the suspects (the parents of the baby), and then sent a letter to the parents stating that the autopsy report was ready and expressing the wish to discuss this within the family circle. The meeting never took place, but the Court of Appeal ruled that this type of (mild) deception was allowed in light of the severity of the accusations. ${ }^{29}$

On 9 January 2018, the Dutch Supreme Court ruled in the case of the imaginary loot set out above that the use of this tactic within the formal context of an interrogation to elicit information from the suspect is permitted under certain circumstances, although this method does not have a statutory basis. ${ }^{30}$ This is because the tactic entails only a limited violation of the rights of the suspect and, in this form, moreover, does not pose a risk to the integrity and controllability of the police investigation. The Supreme Court highlighted the fact that it concerned a very serious offence in which other investigative measures did not have the desired effect,

28 See District Court Noord-Nederland 18 May 2017, ECLI:NL:RBNNE:2017:1824. See for another example in which the police published a fake online article: District Court Oost-Brabant 8 December 2016, ECLI:NL:RBOBR:2016:6805.

29 See Court of Appeal Amsterdam 8 March 2019, ECLI:NL:GHAMS:2019:787.

30 See Supreme Court of the Netherlands 9 January 2018, ECLI:NL:HR:2018:18. 
that the prosecutor had given permission to use this method and that there was an adequate report, which enabled judicial scrutiny. In other words, the Supreme Court gave its approval to this type of method in the specific circumstances of the case, where there is a lot at stake. The fact that the police lied and that they elicited a statement against the will of the suspect was not considered a violation of article 29, paragraph 2 DCCP (setting forth the prohibition on the use of coercion). However, this was a rather mild form of deception, not accompanied by any form of pressure. Whether the suspect would speak or how things would develop, was outside the range of influence of the police and the prosecutor. ${ }^{31}$

\subsection{The 'Mr. Big' technique}

Another form of trickery used to elicit a statement and thereby circumvent the right to silence, is the use of the so-called 'Mr. Big' technique. ${ }^{32}$ This technique is of an entirely different order and scale. Where the police in the previous strategy only uses noise or fake information to disturb the status quo and set things in motion, in this type of method the police actively tries to obtain a confession, by creating a fake criminal organisation in which the unknowing suspect gradually can secure a position for himself. After undercover agents befriend the suspect and the suspect becomes more involved, he is seduced into confessing to the leader of this fictitious organisation (the so called 'Mr. Big') who can make all his problems disappear. This kind of undercover operation was developed in Canada and can appropriately be characterized as a 'non-custodial interrogation procedure. ${ }^{33}$ In so far as can be derived from published case law, the Mr. Big technique has been employed in at least two cases in the Netherlands. ${ }^{34}$

31 However, in these cases there is a certain risk, since the fact that one person believes that the other has secretly taken part of the loot, may lead to repercussions.

32 See also C. Ganzeboom, 'De Mr. Big-methode: een uitzondering op het zwijgrecht?', DD 2019/52 en P.J. Van Koppen en R. Horselenberg, 'Van toneelspelende politiemensen en onwetende verdachten die bekennen tegen Mr. Big, Strafblad 2018/19.

33 See in more detail S.M. Smith, V. Stinson \& M.W. Patry, 'Using the 'Mr. Big' technique to elicit confessions: Successful innovation or dangerous development in the Canadian legal system, Psychology Public Policy and Law 2009, 15/3, p. 168-170. See also: E.W. Kruisbergen, Combating organized crime: A study on undercover policing and the follow-the-money strategy (diss. VU Amsterdam), 2017.

34 See Court of Appeal 's-Hertogenbosch 5 February 2018 ECLI:NL:GHSHE: 2018: 421 (Kaatsheuvel case) with conclusion of Attorney General Machielse 25 Septem- 
One of these cases was the Kaatsheuvel case, which concerned the murder of a woman, mother of two children. In this case the husband was suspected due to - among other things - the incongruities in his statement and the fact that he was having an affair with another woman who was pressuring him to choose between her and his wife. The suspect had been put in pre-trial detention, but there was not enough evidence to prosecute him and he had to be released after three months. From that moment the investigation apparently stopped. Three years had passed, when two persons, Katja en Joep (in reality undercover agents of the Dutch police), rang at the suspect's door telling him that they had accidentally collided with his car. After this initial contact was made, they gradually became friends and the suspect did more and more assignments for the security company owned by Joep. When, after some time, the suspect asked for a permanent position within the company, Joep told him that he first had to have an interview with the big boss of the company, Philipe, who lived in a villa in Marbella. Both men travelled to Spain. During their trip, Joep told the suspect that he had once run over and killed a woman and Philipe solved all his problems with the authorities. In the interview, Philipe asked the suspect to give full disclosure on the case of the murder of his wife, which Philipe had heard about via corrupt sources within the Dutch police. Philipe told the suspect that he could only work for him if he told Philipe the whole story, in order to avoid any future surprises, and Philipe offered to help the suspect arrange an alibi or to fabricate evidence against someone else. At the same time, Philipe warned the suspect that if he did not tell him what had happened, he would lose his position within the organization and the lucrative jobs he was doing. At first, the suspect did not make a confession to Philipe, but during a second interview - after having spoken to Joep - he finally did. Altogether, the whole operation took a year. After the police arrested the suspect, he retracted his confession saying that Philipe pressured him into confessing and he had just put up a show. $^{35}$

ber 2018, ECLI:NL:PHR:2018:1042 and Court of Appeal Arnhem-Leeuwarden 15 March 2018, ECLI:NL:GHARL:2018:2415 (Posbank case) with conclusion of Attorney General Bleichrodt 18 June 2019, ECLI:NL:PHR:2019:648.

35 The details of the case are partly derived from D. Aben, 'De twee sirenen van het bewijs: over daderkennis en over ongewilde bekentenissen (aan Mr. Big)', Expertise en Recht 2020/1; and from Van Koppen en Horselenberg 2018. See for more details: Court of Appeal 's-Hertogenbosch 5 February 2018 ECLI:NL:GHSHE:2018: 421 with conclusion of Attorney General Machielse 25 September 2018, ECLI: NL:PHR:2018:1042. 
The problem with this kind of operation, apart from the fact that they are very costly and time-consuming, lies in the relatively high risk of eliciting false statements in comparison to interrogations that take place within the normal setting of a police station. Part of the technique is that the suspect is lured into a situation in which he has much to gain when he confesses and much to lose when he refuses to do so. In other words, the incentive to confess is very large, especially because the suspect might feel obliged to do something in return for all the benefits he has already received and might feel intimidated by an organization with a history of violence. ${ }^{36}$ Not only is the reliability of the confession at stake, there is also the problem that it is not easy for a suspect to just walk away, because of the financial and social allurements of being part of this organization and the possible consequences of leaving. This raises the question of whether the confession could be considered to have been made voluntarily.

Recently, the Dutch Supreme Court ruled in both cases in which the Mr. Big technique was employed, annulling both decisions and referring them back to the Court of Appeal. ${ }^{37}$ In both cases, the evidence rested heavily upon the confession made during the undercover operation. The Dutch Supreme Court attaches importance to the following factors when determining whether the confession was made voluntarily or not: a) the course of the investigation; b) to what extent the police put psychological pressure on the suspect; c) if applicable, the position originally taken by the suspect in relation to the facts he was suspected of (i.e. whether he exercised his right to silence); d) the degree and form of trickery used during the operation; e) the degree of interference of the undercover agents regarding the content of the statement made by the suspect; $f$ ) the duration and intensity of the operation; $\mathrm{g}$ ) the tenor and frequency of the communications with the suspect; and $h$ ) the positive or negative consequences of clarifying or not clarifying certain aspects of the case, as portrayed to the suspect.

36 See the conclusion of Attorney General Machielse 25 September 2018, ECLI: NL:PHR:2018:1042, $\mathbb{2} 27$. In these type of undercover operations agents make also use of minimization and maximization strategies in which the severity of the crime and the consequences of confessing are minimalized (because Mr. Big will help to dispose of the evidence or solve the problem with justice), while the consequences of denial are maximized (because then the defendant cannot reach the higher echelons of the organization and might lose his friends and lucrative business). See W.D. Woody and K.D. Forrest, Understanding police Interrogations: Confession and Consequences, New York: New York University Press 2020, p. 100.

37 See Supreme Court of the Netherlands 17 December 2019, ECLI:NL:HR:2019: 1982 and ECLI:NL:HR:2019:1983. 
In both cases, the Courts of Appeal had ruled that the confessions were made voluntarily. In light of the foregoing criteria, however, the Dutch Supreme Court found that the appellate courts had not adequately motivated their decisions. The question is whether, in light of the Supreme Court's findings in these cases, this type of method fits within the Dutch criminal justice system and could be employed in the future. Looking at the foregoing criteria and the strictness with which the Supreme Court evaluated the reasoning adopted by the appellate courts, there does not seem to be much leeway for the police in this regard. At the same time, the Supreme Court did not rule that these methods are by definition incompatible with the right to silence.

When looking at the recent jurisprudence on the noise strategy and the Mr. Big method, it is clear that the Dutch Supreme Court does not object to the use of techniques aimed at eliciting involuntary and incriminating information from the suspect in cases in which the suspect had previously elected to remain silent. The use of undercover methods always involves an element of deception. Illustrative in this regard is the (older) jurisprudence on the jail-informant. ${ }^{38}$ What is new, however, is that the Dutch Supreme Court allows for (mild forms of) trickery or deception within the formal setting of the interrogation and that in the Mr. Big cases, the Supreme Court set boundaries for the police in this regard.

The question is now which rationale for the right to silence the Dutch Supreme Court is protecting in the Mr. Big case law. From the aforementioned case on the imaginary loot we may deduce that the protected rationale is not the autonomy of the suspect to decide whether or not to cooperate with the authorities by making a statement. Most likely, the concerns of the Supreme Court have more to do with the reliability of the information the police so cunningly obtained. In the case of the imaginary loot, this was not a problem because the police could rely on the fact that only a truly guilty person would act upon this information (others would not have known what the perpetrators took away). As we already addressed, the Mr. Big method does pose a serious risk to the reliability of the information provided, especially because that information cannot be said to have given spontaneously. There are of course strategies that courts can use to assess the reliability of the confession, for example, assessing whether the information provided by the suspect is information that only a true

38 See Supreme Court of the Netherlands 9 March 2003, ECLI: NL: HR: 2004: AN9195. 
perpetrator could possess (so called 'guilty knowledge'). ${ }^{39}$ If the remains in a murder case are missing and the confession of the suspect leads to their discovery, the reliability of the confession can be established in retrospect. However, the fact that the Supreme Court does not mention reliability as a factor to be taken into account in determining whether the confession was made voluntarily, might suggest that this is not the only rationale that the Supreme Court is seeking to protect. ${ }^{40}$

Perhaps we must also consider this in relation to what a suspect, who is presumed innocent until proven otherwise, has to endure. The right to silence and the presumption of innocence also protect the innocent suspect from constant and endless harassment by the police. The methods used in the Mr. Big cases encroach deeply on the personal lives of the suspects involved, while there is no certainty as to their guilt. If that certainty were to exist, there would be no need for such a costly and time-consuming operation. ${ }^{41}$ In other words, the right to silence (as a counterpart of the prohibition on the use of coercion directed to the police), may also be viewed as a right not to be pressured by the police, at least not unduly so. In our view, this is a different rationale to the autonomy rationale, which is concerned with the suspect's ability to choose whether or not to cooperate with the investigative authorities. ${ }^{42}$

\subsection{Adverse inferences}

Another example of circumventing or at least limiting the effects of a suspect or accused invoking his right to silence is the drawing of adverse inferences (negative conclusions) from his decision to remain silent or not provide information to support his version of the events. The right to silence implies that the accused can choose freely whether to give a statement and that that choice should not be used against him. When judges deduce from the accused's silence that there is nothing to count in his favor and use this to establish the accused's guilt, moreover, they discourage those who may

39 In the Posbank case the Court of Appeal had explicitly explained that the confession was reliable because it was corroborated with other independent evidence and the defendant had so-called 'guilty knowledge'. See Court of Appeal ArnhemLeeuwarden 15 March 2018, ECLI:NL:GHARL:2018:2415.

40 See also Aben 2020, p. 8.

41 This would not meet the criteria of proportionality and subsidiarity the legislator and the Supreme Court set for the use of undercover operations.

42 See section 3. 
rely on it from doing so. ${ }^{43}$ Nevertheless, although the use of adverse inferences encroaches on the right to silence, the ECtHR allows for it under certain circumstances on the basis that the right to silence is not an absolute right. Adverse inferences are permitted, as long as they do not violate article 6 ECHR and the fairness of the procedure as a whole. The Court does, however, state that the right to silence lies 'at the heart of the notion of a fair procedure under article $6^{\prime 44}$ and therefore limits the ability of domestic courts to draw adverse inferences from the silence of the accused. While the ECtHR stipulates that it is incompatible with the right to silence to base a conviction solely or mainly on the accused's silence or on a refusal to answer questions or to give evidence himself', it is allowed in situations 'which clearly call for an explanation. 45 Put differently, adverse inferences are permitted 'provided that the evidence is such that the only commonsense inference to be drawn is that the accused has no answer to the case against him. ${ }^{46}$

The question remains as to what exactly the silence of the accused proves. That the accused does not wish to give a statement does not mean he is guilty. He could well have other motives for not giving a statement. Interesting in this regard is the research of Kassin suggesting that 'actual innocence' can be more of a handicap in the procedure, because - among other things - innocent people may believe naively in the transparency of their innocence. ${ }^{37}$ In other words, courts should be careful not to place too much weight on the fact that the accused has not provided a satisfactory explanation. In any case it is clear that the fewer limitations there are on the use of adverse inferences, the more the right to silence is eroded. It is

43 See Bemelmans 2018, p. 253-258.

44 See for example John Murray v. the United Kingdom, ECtHR (GC) 8 February 1996, no. 18731/91, $\$ 45$ and Bykov v. Russia, ECtHR (GC) 10 March 2009, no. 4378/02.

45 See e.g. John Murray v. the United Kingdom, ECtHR (GC) 8 February 1996, no. 18731/91, \47; Telfner v. Austria, ECtHR 20 March 2001, no. 33501/96, $\$ 18$; and Natunen v. Finland, ECtHR 31 March 2009, no. 21022/04, $\$ 54$.

46 See Telfner v. Austria, ECtHR 20 March 2001, no. 33501/96, $\$ 17 ;$ Krumpholz v. Austria, ECtHR 18 March 2010, no. 13201/05, $\$ 33$. The ECtHR uses the first criterion (clearly calls for an explanation) in cases from common law systems, and the second in relation to civil law countries. See G.H. Meijer en R. ter Haar, 'Zwijgrecht en procesopstelling: het toenemende belang van het uitblijven van een aannemelijke verklaring op de bewijsbeslissing, TPWS 2018, $\mathbb{} 2$.

47 According to this research innocent persons also 'elicit highly confrontational interrogations', despite or because of their denials. See S.M. Kassin, 'On the Psychology of Confessions: Does Innocence Put Innocents at Risk?', American Psychologist, 2005-3, p. 215-228. 
understandable, therefore, that under the case law of the ECtHR, the case against the accused must be quite strong before courts are allowed to take the accused's silence into account adversely. The ECtHR speaks of a 'formidable' or 'prima facie' case in this regard. ${ }^{48}$ According to the ECtHR, the expression 'prima facie case' in the Anglo-Saxon context was intended 'to denote a case which is strong enough to go to a jury - i.e. a case consisting of direct evidence which, if believed and combined with legitimate inferences based upon it, could lead a properly directed jury to be satisfied beyond reasonable doubt ... that each of the essential elements of the offence is proved. ${ }^{39}$ Somewhat paradoxically, therefore, the ECtHR appears to permit the use of adverse inferences in circumstances in which they are not needed to secure a conviction. ${ }^{50}$ According to the ECtHR, the fact that the accused did not give an explanation may only 'be taken into account in assessing the persuasiveness of the evidence adduced by the prosecution. ${ }^{51}$ In the case law of the Dutch Supreme Court, however, it seems that adverse inferences may play a greater role than that envisaged by the ECtHR.

In the Netherlands, the position adopted by the accused in terms of whether to give a statement has become increasingly important in the past years. Although the Dutch Supreme Court explicitly states that the silence of the accused is not considered to constitute evidence as such, the Court has, in recent case law, highlighted the fact that if the accused cannot (or will not) give a reasonable explanation that could refute the probative value of the evidence against him, the court may take this into consideration..$^{52}$ The question that then arises is whether the silence can also be used to 'mend' a hole in the 'evidentiary construction'. In other words: is the use

48 See regarding the (subtle) difference between both criteria Meijer \& Ter Haar 2018, $\mathbb{\$}$ 3. See in this regard also Supreme Court of the Netherlands 5 May 2012, ECLI:NL:HR:2012:BW7372.

49 See John Murray $v$. the United Kingdom, ECtHR (GC) 8 February 1996, no. 18731/91, where lord Mustill from the Irish court is quoted.

50 See about this contradiction also the concurring opinion of Wojtyczek in the case of O'Donnell v. the United Kingdom, ECtHR 7 April 2015, no. 16667/10: 'The explanations of the accused are simultaneously seen as necessary, as the situation calls for an explanation, and unnecessary, as there is other strong evidence on which to base his conviction. If in a specific case there is sufficient evidence to decide a case without drawing any inferences from the accused's silence, then there is no need to resort to any adverse inferences from his silence in deciding the case'

51 See John Murray $v$. the United Kingdom, ECtHR (GC) 8 February 1996, no. 18731/91, $\$ 47$ (emphasis added).

52 See Supreme Court of the Netherlands 28 November 2017, ECLI:NL:HR:2017: 3022 and Supreme Court of the Netherlands 5 July 2016, ECLI: NL:HR:2016: 1315. 
of adverse inferences allowed in cases in which the available evidence does not (provisionally) prove the guilt of the accused? In his concurring opinion in the ECtHR case of O'Donnell v. the United Kingdom, Judge Wojtyczek reflected on this question as follows.

'From the viewpoint of the protection of various public interests, limitations on the right to silence might only have an added value if there are difficulties with establishing the facts, especially if the evidence produced is insufficient for the guilt of the accused to be ascertained whereas there is a serious risk that an offence may go unpunished. In other words, inferences from the silence of the accused may appear necessary only if, in some types of cases, they may tip the balance in the process of establishing the facts. 53

It is difficult to discern from the case law of the Dutch Supreme Court and the ECtHR how strong a case must be before a court is allowed to draw adverse inferences and what weight can be attached to the suspect's silence. It is clear, however, that the Supreme Court is sailing close to the wind on this matter.

The case law on participation or co-perpetration (entailing the cooperation of two or more people in committing an offence) is particularly illustrative in this regard. According to the case law of the Dutch Supreme Court, a person may be held liable as a full perpetrator (or co-perpetrator) if his intellectual and/or material contribution to the criminal act is of sufficient weight. ${ }^{54}$ If not, he can only be convicted as an accomplice or be acquitted. This case law poses serious evidentiary problems in cases in which it was not quite clear what the exact role of each person involved was. In those cases, the position adopted by the accused plays an important role. This is illustrated by a case regarding the burglary of a dentist's surgery where a laptop was taken away. ${ }^{55}$ A short time after the burglary, the police discovered a car near the surgery with several passengers in it.

53 See the concurring opinion of Wojtyczek in the case of O'Donnell $v$. the United Kingdom, ECtHR 7 April 2015, no. 16667/10.

54 According to Supreme Court of the Netherlands 16 December 2014, ECLI: NL: HR:2014:3637, $\$ 3.2 .1-3.2 .3$, relevant factors in this regard are: 'the intensity of the cooperation, the division of tasks in the criminal enterprise, the role of the accused in the preparation, the execution or settlement of the crime and the importance of the role of the accused and his presence at key moments. This translation is extracted from Van Kempen, Krabbe \& Brinkhoff 2019, p. 91.

55 See Supreme Court of the Netherlands 28 November 2017, ECLI:NL:HR:2017: 3022 . 
When the police officers followed the car, the driver tried to shake them of, while the passengers threw burglars' tools out of the window. After stopping the car, the police found the laptop from the surgery in the car and arrested all of the passengers. The Court of Appeal convicted the accused as a co-perpetrator of the burglary, taking into account that he had not given a reasonable explanation for his presence in the car. The Dutch Supreme Court confirmed this conviction, although there was no direct evidence placing the accused at the crime scene, nor was there direct evidence that more than one person had committed the theft.

From this case law, we can conclude that, under certain circumstances, the silence of the accused can be essential for securing a conviction. This is especially so when the court is unable to establish whether the accused has made a significant contribution, which is a prerequisite for a conviction as a full perpetrator. Since, in those cases, the accused is the only one who can clarify his role, the choice to remain silent can be detrimental to the accused's case. ${ }^{56}$ As a result, someone who is actually an accomplice, can be considered a full perpetrator unless he can show that his role was minor. ${ }^{57}$ However, this is only possible within strict conditions, e.g. when the suspect has been found in very suspicious circumstances shortly after the offence has occurred..$^{58}$ In the case of the dentist's surgery, it seems the Supreme Court even went a step further, because in that case, there was no direct evidence of the accused's involvement. It might have been the case that the accused did not have any part in the theft (for example, because he had remained in the car while his friends went out stealing). However, when the accused does not wish to give a statement and there are no indications that he was not involved, under this case law, he can be convicted as (full) perpetrator. ${ }^{59}$

The question is why, in its recent case-law, the Dutch Supreme Court has given more leeway to judges to draw negative inferences from the position of the accused. It might be due to the sharpening of the criteria on co-perpetration in 2014, pursuant to which, in order to be convicted as a

56 See also Meijer \& Ter Haar 2018, $\$ 9$.

57 See also the annotation of Wolswijk under the ruling of the Supreme Court of the Netherlands 28 November 2017, ECLI:NL:HR:2017:3022, NJ 2018/310.

58 See Supreme Court of the Netherlands 5 July 2016, ECLI:NL:HR:2016:1315, and Supreme Court of the Netherlands 5 July 2016, ECLI:NL:HR:2016:1323, $\$ 4.3 .2$.

59 See Supreme Court of the Netherlands 28 November 2017, ECLI:NL:HR:2017: 3022, $\$ 2.3 .3$. In Supreme Court of the Netherlands 5 July 2016, ECLI:NL:HR: 2016:1319, there were contraindications because the accused did not fit the description of the persons who committed the theft. 
full perpetrator, there should be a contribution of significant weight. The purpose of this sharpening was to delineate more clearly the roles of the full perpetrator and the accomplice, but it also raises the standard for all cases in which more than one person is involved in the criminal act. The sharpened criteria could lead to problems (and perhaps acquittals) in cases in which the defendants elect to remain silent and the court can establish neither capacities, because each person's part remains unclear. The approach of the Dutch Supreme Court helps to overcome these evidential problems. Another explanation that is perhaps more plausible, is the fact that since 2010, the suspect has access to a lawyer before the interrogations starts. Research has shown that the police are of the impression that suspects are increasingly invoking their right to silence, which they attribute (in part at least) to the aforementioned development. Although the research on this topic is somewhat ambiguous, the willingness of suspects to give a statement does seem to have diminished in recent years. ${ }^{60}$ The question is whether the Supreme Court has been compensating for this or has had other reasons to loosen the reins somewhat. Arguably, it is more justifiable (or at least: less problematic) to allow for the drawing of adverse inferences if this person has had the benefit of legal assistance and has had the opportunity to make an informed decision as to whether to invoke his right to silence. Nevertheless, all this remains speculative in the absence of an explanation from the Supreme Court, but it is hardly surprising that this case law has come at this point in time.

\subsection{Evidentiary presumptions}

Another way of circumventing the right to silence, and lighten the burden of proof on the prosecution, is the use of an evidentiary presumption (also called a presumption of fact). These allow courts to assume a fact is true unless there is evidence to prove otherwise. The basis of this presumption are the other facts at hand that make the presumed fact more likely, because there is an (assumed) causal or statistical connection between the established facts and the assumed fact. ${ }^{61}$ The fact that it is a presumption implies that the court must take into account that things could be different than they appear to be at first sight. However, it is up to the accused to re-

60 See C.M. Klein Haarhuis, Lange termijnmonitor raadsman bij het verhoor, Wetenschappelijk Onderzoek- en Documentatiecentrum Cahier 2018-16.

61 See Bemelmans 2018, p. 137. 
but the presumption and to claim that it does not apply in his specific case. Therefore, it shifts the burden of proof from the prosecutor to the accused and has, in this regard, direct consequences for the exercise of the right to silence. After all, it means that the innocent accused cannot invoke his right to silence without risking a wrongful conviction. ${ }^{62}$ The question is when the use of this type of evidentiary presumption is permitted. The case law of the ECtHR allows quite a lot leeway in this regard, as long as the use of these presumptions stays within reasonable limits. ${ }^{63}$ At the same time, however, the case law of the ECtHR gives little guidance to national courts as to when these limits will have been exceeded. ${ }^{64}$ The Dutch system also lacks a clear framework for answering these type of questions.

In the Netherlands, courts explicitly use evidentiary presumptions in cases of money laundering. The law states that to convict someone for money laundering, the money or goods in question must have originated from a criminal offence (see article 420bis of the Dutch Criminal Code). However, the court does not need to establish the specific criminal offence from which the money or goods have originated. ${ }^{65}$ When it is not possible to establish a direct connection with a specific criminal offence (such as theft), the court may nevertheless establish that the object at stake has a criminal origin if there is no other reasonable conclusion. ${ }^{66}$ Another prerequisite for a conviction is that it is established that the accused was trying to conceal the origins of the money or goods. Because this is difficult to prove, judges may use so called 'money laundering typologies'; these are specific circumstances or characteristics which are indicative of laundering. From these more or less objective characteristics, a suspicion of money laundering may be derived.

For example, when the police stops someone at the border with a large amount of cash, this might be an indication that he is involved in money laundering. The line of reasoning is that normally people do not carry such large amounts of cash because of the safety risks involved. This, therefore, calls for an explanation. If the accused fails to provide such a reasonable explanation, the presumption of money laundering will easily shift to

62 See Bemelmans 2018, p. 377.

63 See for example Salabiaku v. France, ECtHR 7 October 1988, no. 10519/83.

64 See Bemelmans 2018, p. 252.

65 See Supreme Court of the Netherlands 27 September 2005, ECLI:NL:HR:2005: AT4094.

66 See Supreme Court of the Netherlands 29 March 2011, ECLI: NL: HR: 2011: BO2628 and Supreme Court of the Netherlands 18 December 2018, ECLI: NL: HR:2018:2352. 
proof of money laundering. The judge is justified in doing so, since the assumption is that an innocent person would provide a reasonable explanation for carrying such a large amount of money. However, the judge can only call for an explanation from the accused after the prosecution has provided enough evidence to establish a justified suspicion of money laundering. Moreover, when the accused gives such an explanation, it is up to the prosecutor to further investigate the given scenario. ${ }^{67}$ After all, a conviction is only possible when the court can reasonably exclude the possibility that the money or goods at stake had a legal origin. Nevertheless, the duty of the prosecutor to initiate further investigations only exists if the accused provides a concrete and verifiable explanation that is not highly unlikely at first sight. ${ }^{68}$ If the accused remains silent or does not provide such an explanation (such as to trigger the duty to conduct further investigations), the burden of proof will be met and the alleged fact may be established.

Although the case law of the Dutch Supreme Court provides some guidance for the judge, it remains unclear in which circumstances the judge may use an evidentiary presumption or draw adverse inferences from the silence of the accused. In particular, it remains unclear how strong the case needs to be before the judge may use these methods. The lack of clarity may partly be explained by the inquisitorial roots of the Dutch criminal justice system, in which the judge has historically played an active role and is therefore not (solely) dependent on the information provided to him by the parties and the stance they take in relation to that information. ${ }^{69} \mathrm{Al}-$ though the prosecutor is expected to make his case and to provide incriminating evidence, there is no formal burden of proof. Nor is there an obligation for the defence to actively contribute to the process of truth-finding or to provide exculpatory evidence. In the case of the money laundering, one could argue that, strictly speaking, there is no actual reversal of the burden of proof. After all, if the accused provides a reasonable explanation, it is up to the prosecutor to initiate additional investigations to verify this explanation. ${ }^{70}$ At that point, the defence is not expected to make any further ef-

67 If he does not wish to investigate further, the case probably will result in an acquittal, because the court cannot reasonably exclude the possibility that the money had legal origins.

68 See Supreme Court of the Netherlands 13 July 2010, ECLI:NL:HR:2010:BM0787.

69 See Bemelmans 2018, p. 86.

70 The Supreme Court also states that the accused cannot be required to prove that the object does not have a criminal origin. See Supreme Court of the Netherlands 18 December 2018, ECLI:NL:HR:2018:2352. 
fort. ${ }^{71}$ Initially, however, it is up to the accused to provide some information. If the accused does not provide a concrete and verifiable explanation which is not highly unlikely at first sight, the prosecutor may remain passive, because the judge has enough reasons to convict. The fact that the accused has to provide some information when there is a strong suspicion against him, may in itself be an infringement of the right to silence, but it is not a (full) reversal of the burden of proof.

\section{Conclusion}

In light of the various ways in which the right to silence may be circumvented - as set out in the previous section - the question arises as to what is left of the meaning of the right to silence in the Netherlands. Put differently: What could be said about the rationale for the right to silence, given the apparent acceptance of these circumventions in European and Dutch case law? Are these rationales still wholeheartedly embraced as interests worthy of protection through the right to silence, or has their (relative) weight gradually changed in the course of time? And if the latter is the case, which factors could explain this development? In this final section, we will try to give a beginning of an answer to these questions.

First of all, it is important to note that the right to silence itself and the way it is embedded in the European and Dutch legal framework have not changed recently. The right to silence is still considered a fundamental right, with strong ties with other fundamental principles, such as the right to a fair trial, the presumption of innocence and the privilege against selfincrimination. In 2016, the importance of the right to silence as a fundamental right was even further stressed by adopting the EU Directive on the presumption of innocence. ${ }^{72}$ Furthermore, it should be stressed that although the ECtHR considers the right to silence to be fundamental, it does not constitute an absolute right. The John Murray-case law of the EC-

71 See the annotation of Reijntjes under the decision of the Supreme Court of the Netherlands 9 July 2019, ECLI:NL:HR:2019:1137, NJ 2019/350.

72 See Article 7 of the Directive 2016/343/EU of the European Parliament and of the Council of 9 March 2016 on the strengthening of certain aspects of the presumption of innocence and of the right to be present at the trial in criminal proceedings, OJ 2016, L 65/1. 
tHR on the admissibility of drawing adverse inferences, which dates from the mid-nineties of the last century, is a case in point. ${ }^{73}$

The proper question, therefore, is in which direction the right to silence is moving in the Netherlands: towards a stricter interpretation or towards a looser attitude? In light of the foregoing, it should come as no surprise that the answer to this question is not entirely clear-cut. On the hand, the right to silence has effectively been strengthened by introducing the right of access to a lawyer at the time of questioning, while on the other hand, the case law of the Dutch Supreme Court increasingly allows for the circumvention or infringement on the right to silence. As discussed in the previous section, this case law undoubtedly reveals a more liberal approach to the right to silence. Not in terms of the question of whether the suspect or accused is allowed to invoke his right to silence - which he certainly is but in terms of the admissibility of means to circumvent his silence or of attaching negative consequences thereto. There are certainly limitations, but the analysis of the recent case law shows that the Supreme Court allows the trial judge quite a lot of leeway in adopting methods that in one way or another erode, circumvent or infringe on the right to silence.

As to what this all says about the rationales underlying the right to silence, looking to the European and Dutch case law, protecting the suspect or accused against undue pressure still seems to be considered of paramount importance. For instance, in the two Mr. Big cases discussed above, the Dutch Supreme Court annulled the previous decisions of the Courts of Appeal, because the grounds on which they had decided that the statements of the accused elicited by the Mr. Big technique were made voluntarily, fell short. These decisions of the Supreme Court seem to reveal that the need to protect the suspect or accused from undue pressure still carries much weight in determining whether the right to silence has been respected. They also underline that undue pressure need not be the result of violence or threats during the interrogation, but may also be caused by a combination of specific circumstances, as was the case in the Mr. Big cases.

The same holds true for the interest of reliable truth-finding and the prevention of miscarriages of justice. When the reliability of the outcome of a certain method is at stake, courts will be prepared to exclude these outcomes for epistemological reasons. This does not mean, however, that any method posing a certain risk to the reliability of the statements made by the suspect or accused will be set aside by the court. When the statements

73 See John Murray v. the United Kingdom, ECtHR (GC) 8 February 1996, no. 18731/91. 
of the suspect elicited by the contested method are corroborated by other sources of evidence, the statements may well be allowed as evidence anyway, provided that the statements do not have to be excluded because of other reasons, such as the exercise of undue pressure. The fact that the interest of reliable truth-finding is still considered of paramount importance may further be illustrated by the case law on the use of adverse inferences and of evidentiary presumptions. As explained in the previous section, these instruments are only allowed in evidentially strong cases, as apparent from the ECtHR's case law in particular. To a certain extent, this restraint may be explained by the wish to grant the suspect or accused a certain degree of autonomy to determine his own position during criminal proceedings - only in strong cases would it appear to be reasonable to demand that the suspect or accused gives a statement - but it certainly also has an epistemological background. Using adverse inferences and evidentiary presumptions rashly would undoubtedly increase the risk of unsafe convictions. In that perspective, it is quite worrisome that the Dutch Supreme Court appears to have loosened the reins when it comes to using adverse inferences and evidentiary presumptions.

The rationale for the right to silence which seems to have 'suffered' most under the recent case law, is respect for the autonomy of the suspect or accused to choose his position and strategy in criminal proceedings, as an indispensable part of the right to a fair trial. The Supreme Court's case law on the use of trickery is particularly illustrative in this regard; had the Supreme Court attached more importance to the autonomy rationale, it would have taken a less liberal approach to milder forms of trickery as used in the case of the imaginary loot and would have imposed an outright ban on more serious forms of trickery such as the Mr. Big technique. It did not, however, which may be interpreted as a signal that the wish to grant the suspect or accused full autonomy during criminal proceedings when it comes to his own strategy or position, certainly has its limitations in the sense that this desideratum may be balanced against other interests, such as the interests of the investigation or the prosecution. The practice of drawing adverse inferences and evidentiary presumptions also show that respect for the autonomy of the suspect or accused is not endless. Provided the case is strong enough from an evidentiary perspective, it is not considered unreasonable to expect the suspect or accused to speak up.

The next question is why the Dutch Supreme Court seems to have taken a more liberal approach with regard to the autonomy of the suspect or accused to choose his own strategy. The grounds given in the various judgments of the Supreme Court do not shed much light on this, but the fact that the legal position of the suspect or accused has been strengthened in 
terms of assistance of a lawyer may well be an important factor in this regard. It is not unlikely that the Supreme Court is of the opinion that a suspect or accused who has been assisted by a lawyer from the very beginning, while deserving of respect for his autonomy to make his own choices with regard to his strategy, may be held to these choices once they have been made. In this line of reasoning, it would not be considered unfair to attach consequences to the choice to remain silent, for instance, by drawing adverse inferences when all the other evidence clearly calls for an explanation. The assumption is that a suspect or accused who is assisted by a lawyer will be properly warned regarding these possible consequences and that a persistent choice to remain silent should therefore be made consciously. From the perspective of the Dutch inquisitorial system, where judges have their own responsibility for establishing the facts, this is a somewhat uncomfortable line of reasoning, given also that the suspect or accused cannot be said to bear responsibility for the process of truth-finding. By contrast, in more adversarial systems, in which the process of truthfinding is a joint responsibility of both parties, this is far more common. ${ }^{74}$ Now that, under the influence of ECtHR case law, Dutch criminal procedure is slowly but surely moving in a more adversarial direction, the Dutch Supreme Court seems to be of the view that it is justified in increasingly holding the suspect or accused to his previous procedural choices, provided that, from an evidentiary perspective, the case is strong enough to do so.

To a certain extent, this encroaches on the respect for the autonomy of the suspect or accused as one of the underlying rationales for the right to silence. On the other hand, however, it would be an exaggeration to say that the foundations of the right to silence have been undermined to the extent that they are now devoid of meaning in the Netherlands. The right to silence still rests firmly on the pillars of the wish to protect the suspect or accused against undue pressure during interrogation and the quality of the process of truth-finding. Nevertheless, the more liberal approach to the rationale of respect for the autonomy of the suspect or accused to choose his own strategy does create some leeway to circumvent or curtail the right to silence. In this sense, and to this extent, it may well be appropriate to speak of the erosion of the right to silence in Dutch criminal justice.

74 See Bemelmans 2018, p. 100. 